ISSN 1678-3921

Journal homepage: www.embrapa.br/pab

For manuscript submission and journal contents, access: www.scielo.br/pab

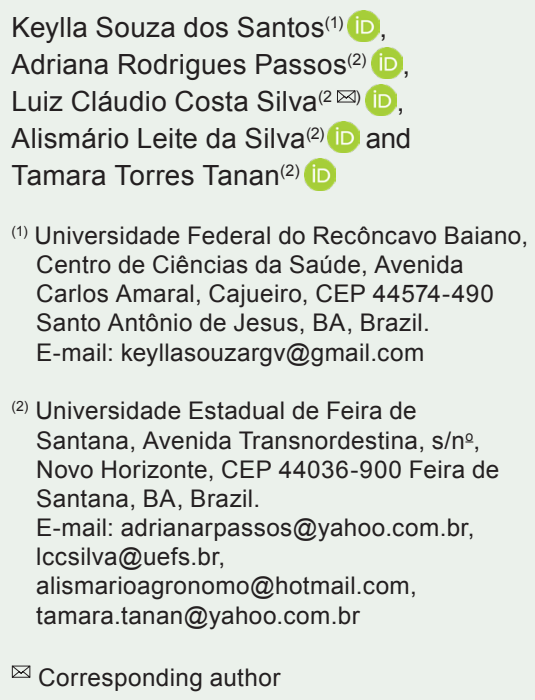

\section{Genetic variability of Physalis ixocarpa and $P$. philadelphica from physicochemical fruit traits}

\begin{abstract}
The objective of this work was to estimate the genetic parameters and genetic divergence of two species of Physalis based on fruit traits, as well as the correlations between these traits. The experiment was carried out in a randomized complete block, with three treatments $(P$. philadelphica and the green and purple varieties of $P$. ixocarpa), and six replicates. The following traits were evaluated: average fruit mass (AFM), soluble solids (SS), longitudinal fruit diameter (LFD), transversal fruit diameter (TFD), total fruit mass (TFM), number of fruit per plant (NF), reducing sugars (RS), and total sugars (TS). Genetic divergence was estimated by Tocher's and the UPGMA methods. There was genetic divergence between the Physalis species, with a higher contribution of AFM, LFD, and TFD, mainly by Tocher's method. A positive correlation was observed between AFM x LFD, AFM x TFD, and LFD x TFD, and a negative correlations between LFD x TFM, TFD x TFM, and NF $x$ RS. The species were discriminated by total sugars. The AFM, LFD, TFD, and TS traits show significant genetic variation and high values of heritability; therefore, they are suitable targets for the genetic breeding of the evaluated Physalis species.
\end{abstract}

Index terms: husk tomato, plant breeding, tomatillo, vegetable crop.

\section{Diversidade genética de Physalis ixocarpa e $P$. philadelphica a partir de características físico-químicas de frutos}

Resumo - O objetivo deste trabalho foi estimar os parâmetros genéticos e a divergência genética de duas espécies do gênero Physalis com base nas características de frutos, bem como as correlações entre essas características. $\mathrm{O}$ experimento foi realizado em blocos ao acaso, com três tratamentos $(P$. philadelphica e as variedades verde e roxa de $P$. ixocarpa) e seis repetições. Avaliaram-se as características: massa média de frutos (AFM), sólidos solúveis (SS), diâmetro longitudinal do fruto (LFD), diâmetro transversal do fruto (TFD), massa total de frutos (TFM), número de frutos por planta (NF), açúcares redutores (RS) e açúcares totais (TS). A divergência genética foi estimada pelos métodos de Tocher e UPGMA. Houve divergência genética entre as espécies de Physalis, com maior contribuição de AFM, LFD e TFD, principalmente pelo método de Tocher. Observou-se correlação positiva entre AFM x LFD, AFM x TFD e LFD x TFD, e correlação negativa entre LFD x TFM, TFD x TFM e NF x RS. As espécies foram discriminadas por açúcares totais. As características AFM, LFD, TFD e TS apresentam variação genética significativa e altos valores de herdabilidade; portanto, são alvos adequados para o melhoramento genético das espécies de Physalis avaliadas.

Termos para indexação: tomate de "cáscara", melhoramento de plantas, "tomatillo", hortaliças. 


\section{Introduction}

The Solanaceae family has many vegetable crop species that are grown for food purposes, including some Physalis species. Tomatillo (Physalis ixocarpa Brot. ex Hornem. and P. philadelphica Lam.), also known as "tomate verde" (green tomato) and "tomate de cáscara" (husk tomato), is a vegetable crop studied in a diversity center in Mexico, and it is widely used in the food sector (Peña-Lomelí et al., 2004; DelgadoAlvarado et al., 2018). Its fruit can be green, yellowgreen, or purple, depending on the cultivated variety (Barroso et al., 2018), and are used to make salads, soups, stews, and sauces (Santiaguillo Hernández \& Blas Yáñez, 2009; Barroso et al., 2017). In addition, both species are used in the traditional medicine for the treatment of fever, cough, and tonsillitis (Maldonado et al., 2011). Besides sharing the same names in some locals, these species show morphological similarities, thus, some studies describe $P$. ixocarpa as a synonym for $P$. philadelphica (Waterfall, 1967; Santiaguillo Hernández \& Blas Yáñez 2009; Naumova et al., 2019). However, differences between their flowers and fruit have led many authors to describe these species as distinct (Lagos B. et al., 2005; Zamora-Tavares et al., 2015; Martínez et al., 2017). The flowers of $P$. ixocarpa are hermaphrodite; however the species is considered cross-pollinated because it shows a selfincompatibility system (Peña-Lomelí et al., 2008); besides, only $40 \%$ of its flowers are pollinated, and $30 \%$ of the pollinated flowers produce mature fruit (Peña-Lomelí et al., 2004; Santiaguillo Hernández et al., 2012). Likewise, $P$. philadelphica shows hermaphrodite flowers and is self-incompatible (Zamora-Tavares et al., 2015).

There are no records of tomatillo commercial cropping in Brazil, but seed trade can be found in online sales platforms. The tomatillo crop in Brazil requires the generation of cultivars with enhanced agronomical and physicochemical characteristics of fruit, in order to meet the needs of market and crop system, such as field performance, growth habit, yield, homogeneous maturity, color, form, size and composition of the fruit (Peña-Lomelí et al., 2008). Therefore, geneticists and breeders have studied these characters to estimate the $P$. ixocarpa genetic parameters to assist in the definition of strategies for selection that lead to higher genetic gains. In the same way, estimating the correlations between different important traits is also relevant when facing the need to deal with multiple traits in plant breeding. This is a key point to develop new cultivars better adopted by the production systems. However, there are few morphological and physicochemical characterization studies of $P$. ixocarpa and $P$. philadelphica in the literature (Peña-Lomelí et al., 2004; Singh et al., 2013; Naumova et al., 2019), and there are no such studies for the Brazilian conditions.

The objective of this work was to estimate the genetic parameters and the genetic divergence of two Physalis species based on fruit traits, as well as the correlations between traits.

\section{Materials and Methods}

The study was carried out in the experimental field of Horto Florestal, at the Universidade Estadual de Feira de Santana, in the municipality of Feira de Santana $\left(12^{\circ} 16^{\prime} 10.29^{\prime \prime S}, 38^{\circ} 56^{\prime} 18.64^{\prime \prime} \mathrm{W}\right.$, at $243 \mathrm{~m}$ altitude) in the state of Bahia, Brazil. The climate is classified as Aw (tropical wet-dry climate), according to the Köppen-Geiger's classification, annual means of $23^{\circ} \mathrm{C}$ temperature and $888 \mathrm{~mm}$ rainfall. The soil at the experimental site is classified as a clayey Latossolo Vermelho eutrófico, according to the Brazilian soil classification system (Santos et al., 2013), i.e., Oxisol.

The experiment was carried out in randomized complete block design, with the three treatments the green and purple varieties of $P$. ixocarpa, and $P$. philadelphica -, with six replicates, and experimental plot with six plants.

Seed from the green and purple varieties of $P$. ixocarpa were acquired from Johnny's Seeds (Winslow, ME, USA), and seed from $P$. philadelphica were acquired from Reimer Seeds (Saint Leonard, MD, USA). The sowing was performed in greenhouse, in cups containing local vegetable soil and the commercial substrate TechnsVivato (biostabilized pine bark, vermiculite, fine charcoal, water, and phenolic foam), at 3:1 proportion. After 15 days, the seedlings were transplanted to the experimental field. The plants were cultivated from May to July 2017. Soil chemical characteristics in the arable layer $(0-20 \mathrm{~cm})$ were determined according to the methods of Raij et al. (2001), as follows: $4.36 \mathrm{pH}\left(\mathrm{H}_{2} \mathrm{O}\right) ; 11.3 \mathrm{~g} \mathrm{dm}^{-3}$ organic matter; $26.7 \%$ base saturation; $0.6 \mathrm{cmol}_{\mathrm{c}} \mathrm{dm}^{-3} \mathrm{Ca} ; 0.4$ $\mathrm{cmol}_{\mathrm{c}} \mathrm{dm}^{-3} \mathrm{Mg} ; 0.11 \mathrm{cmol}_{\mathrm{c}} \mathrm{dm}^{-3} \mathrm{Na} ; 3.26 \mathrm{cmol}_{\mathrm{c}} \mathrm{dm}^{-3}$ $\mathrm{H}+\mathrm{Al} ; 3 \mathrm{mg} \mathrm{dm}^{-3} \mathrm{P}$ (Mehlich-1); $33 \mathrm{mg} \mathrm{dm}^{-3} \mathrm{~K}$. The soil

Pesq. agropec. bras., Brasília, v.56, e01534, 2021

DOI: 10.1590/S1678-3921.pab2021.v56.01534 
has a sandy clay loam texture, containing $737 \mathrm{~g} \mathrm{~kg}^{-1}$ sand, $62 \mathrm{~g} \mathrm{~kg}^{-1}$ silt, and $201 \mathrm{~g} \mathrm{~kg}^{-1}$ clay.

Ripe fruit were collected and evaluated in the Laboratory of Molecular Genetics and in the Laboratory of Seed Germination, at Universidade Estadual de Feira de Santana. The evaluated characteristics were: average fruit mass (AFM, g), obtained from five fruit harvested at random; longitudinal fruit diameter (LFD, $\mathrm{mm}$ ), obtained from five fruit harvested at random; transversal fruit diameter (TFD, mm), obtained from five fruit harvested at random; total fruit mass (TFM, g), mass of all fruit from one plant; number of fruit per plant (NF), score of fruit per plant; soluble solids (SS, ${ }^{\circ}$ Brix), obtained from five fruit harvested at random; reducing sugars (RS, $\mathrm{mm} \mathrm{g}^{-1}$ of fresh weight), obtained from five fruit harvested at random; total sugars (TS, $\mathrm{mm} \mathrm{g}^{-1}$ of fresh weight), obtained from five fruit harvested at random, by the anthrone method (Yemm \& Willis, 1954).

Data were analyzed concerning normality and homoscedasticity by the Shapiro-Wilk's and Bartlett tests, respectively. The existence of genetic variability for the traits was detected by using the analysis of variance, and the mean comparisons were performed by the Tukey's test.

The following genetic parameters were estimated: phenotypic variance $\left(\sigma_{\mathrm{f}}^{2}\right)$; mean environmental variance $\left(\sigma_{\mathrm{e}}^{2}\right)$; mean genotypic variance $\left(\sigma_{\mathrm{g}}^{2}\right)$; coefficient of genetic variance $\left(\mathrm{CV}_{\mathrm{g}}\right)$; coefficient of environmental variance $\left(\mathrm{CV}_{\mathrm{e}}\right)$; and broad sense heritability $\left(\mathrm{h}^{2}\right)$. Phenotypic correlations between the characters were estimated by the Pearson's coefficient, and their significance were evaluated by t-test.

Multivariate methods were used for the genetic divergence analysis. The Mahalanobis' generalized distance was calculated as a dissimilarity measure, to perform grouping analysis by optimization (Tocher) and hierarchical (UPGMA) methods. The groupings generated by UPGMA were validated by cophenetic correlation coefficient (Sokal \& Rohlf, 1962), and the significance of this coefficient was analyzed by the Mantel's test based on 5,000 simulations (Mantel, 1967). Statistical analyses were estimated using the software GENES (Cruz, 2013). The cut-off point of the dendrogram was estimated by the method described by Mojena (1977), obtained by "NbClust" of R library package (Charrad et al., 2014), and the relative contribution of the characters for the genetic divergence was determined using the criterion proposed by Singh (1981).

\section{Results and Discussion}

All descriptors showed normal distribution and homoscedasticity, except for TFM, which did not show normal distribution, and NF, which did not show homoscedasticity. The physicochemical descriptors detected genetic variability between $P$. philadelphica and $P$. ixocarpa varieties green and purple (Table 1). AFM showed significant variation at $1 \%$ probability, while LFD, TFD, and TS showed a significant variation, at $5 \%$ level of probability. SS, TFM, NF, and RS showed no significant variation between treatments.

The coefficients of variation varied from $11.03 \%$ (LFD) to $68.48 \%$ (TFM). LFD, TFD, and SS had the lowest $\mathrm{CV}_{\mathrm{e}}(11.03,12.5$, and $13.04 \%$, respectively), indicating a good homogeneity of the data, while TS and AFM showed the mean homogeneity of 24.21 and $27.92 \%$, respectively. Similar CV values were found by Silva et al. (2019), who evaluated $P$. angulata fruit traits. They found values varying from $8.78 \%$ (fruit transversal length) to $68.21 \%$ (number of fruit per plant). High values of $\mathrm{CV}$ were expected in the present study, since the species are cross-pollinated, and the genotypes did not undergo an improvement process in Brazilian conditions.

The species $P$. philadelphica showed a higher TS concentration (36.45 $\mathrm{mg} \mathrm{g}^{-1}$ ), statistically differing from the green (24.45 $\left.\mathrm{mg} \mathrm{g}^{-1}\right)$ and purple (22.87 $\left.\mathrm{mg} \mathrm{g}^{-1}\right)$ varieties of $P$. ixocarpa (Table 2). This trait was the only one that could separate the two species. The form of the stigma and size of flower and fruit are the main differences between these two species (Lagos B. et al., 2005; Zamora-Tavares et al., 2015; Martínez et al., 2017). Thus, the total sugar content in the fruit may be a new trait that can distinguish $P$. ixocarpa from $P$. philadelphica. The TS values of $P$. ixocarpa from $P$. philadelphica were lower than those found in other Physalis species, as follows: $64.5 \mathrm{mg} \mathrm{g}^{-1}$ in $P$. angulata, observed by Oliveira et al. (2011); $60.0 \mathrm{mg} \mathrm{g}^{-1}$ in $P$. angulata and $P$. pubescens, found by Golubkina et al. (2018); and $63.90 \mathrm{mg} \mathrm{g}^{-1}$ in P. peruviana, reported by Yildiz et al. (2015). These values are expected, since $P$. angulata and $P$. peruviana are considered fruit and consumed in natura or used to make jellies and 
candies, requiring a higher concentration of sugars, while tomatillos are considered vegetable crops, and are used commonly to make salads, stews, and sauces (Barroso et al., 2017).

Concerning AFM, the green variety of $P$. ixocarpa showed fruit with higher mass $(74.22 \mathrm{~g})$, while $P$. philadelphica showed fruit with lower mass (40.22 g), which are higher values than those of other published studies. Singh et al. (2013) and Peña-Lomelí et al. (2004) found $27.18 \mathrm{~g}$ and $33.8 \mathrm{~g}$ per fruit of $P$. ixocarpa, respectively, while Naumova et al. (2019) found the average of $17.0 \mathrm{~g}$ per fruit of $P$. philadelphica.
Therefore, the green variety of $P$. ixocarpa showed potential to be cultivated and to produce fruit with high mass values in local conditions.

The traits AFM, LFD, TFD and TS showed a higher genetic variation in comparison with the environmental variation, as proven by the $\mathrm{CV}_{\mathrm{g}}$ values, since these coefficients are employed to prove the genetic variability in a population for each evaluated trait (Table 2). Therefore, as higher the $\mathrm{CV}_{\mathrm{g}}$ estimate, the more effective the selection and higher the possibility of genetic gain. In the present study, the $\mathrm{CV}_{\mathrm{g}}$ varied from $9.51 \%$ (LFD) to $30.60 \%$

Table 1. Analysis of variance from eight fruit traits of Physalis ixocarpa and P. philadelphica.

\begin{tabular}{lccccccccc}
\hline \multirow{2}{*}{$\begin{array}{l}\text { Source of } \\
\text { variation }\end{array}$} & DF & \multicolumn{9}{c}{ Mean square } \\
\cline { 2 - 10 } & & AFM & SS & LFD & TFD & TFM & NF & RS & TS \\
\hline Block & 5 & 899.51 & 0.28 & 22.50 & 43.95 & $99,476.79$ & 400.67 & 11.64 & 91.95 \\
Genotype & 2 & $1,887.15^{* *}$ & 0.11 & $40.41^{*}$ & $62.77^{*}$ & $14,562.29$ & 337.50 & 10.83 & $330.91^{*}$ \\
Residual & 10 & 229.93 & 0.27 & 7.41 & 10.97 & $37,105.82$ & 161.37 & 5.64 & 45.68 \\
\hline Mean & & 54.31 & 4.01 & 24.67 & 26.48 & 281.28 & 20.05 & 7.36 & 27.92 \\
CV (\%) & & 27.92 & 13.04 & 11.03 & 12.51 & 68.48 & 63.36 & 32.27 & 24.21 \\
\hline
\end{tabular}

*,**Significant at 5 and $1 \%$, respectively, by the F-test. DF, degree freedom. Fruit traits: AFM, average fruit mass; SS, soluble solids; LFD, longitudinal fruit diameter; TFD, transversal fruit diameter; TFM, total fruit mass; NF, number of fruit; RS, reducing sugars; TS, total sugars.

Table 2. Genetic parameters, minimal and maximal values, and mean comparison by the Tukey's test, for four fruit traits of Physalis ixocarpa and P. philadelphica.

\begin{tabular}{|c|c|c|c|c|}
\hline Parameter & $\operatorname{AFM}(\mathrm{g})$ & $\mathrm{LFD}(\mathrm{mm})$ & TFD (mm) & $\mathrm{TS}\left(\mathrm{mg} \mathrm{g}^{-1}\right)$ \\
\hline Minimal & 24.31 & 17.79 & 19.05 & 9.56 \\
\hline Maximal & 108.91 & 33.06 & 39.12 & 46.89 \\
\hline$\overline{\sigma_{\mathrm{F}}{ }^{2}}$ & 314.52 & 6.73 & 10.46 & 55.14 \\
\hline$\sigma_{\mathrm{A}}^{2}$ & 38.32 & 1.23 & 1.83 & 7.61 \\
\hline$\sigma_{\mathrm{G}}^{2}$ & 276.20 & 5.50 & 8.63 & 47.53 \\
\hline $\mathrm{CV}_{\mathrm{g}}(\%)$ & 30.60 & 9.51 & 11.10 & 24.69 \\
\hline $\mathrm{CV}_{\mathrm{g}} / \mathrm{CV}_{\mathrm{e}}$ & 1.10 & 0.86 & 0.89 & 1.02 \\
\hline \multirow[t]{2}{*}{$h^{2}(\%)$} & 87.82 & 81.67 & 82.52 & 86.19 \\
\hline & \multicolumn{4}{|c|}{ Mean comparison } \\
\hline P. philadelphica & $40.20 \mathrm{~b}$ & $22.49 b$ & $23.88 \mathrm{~b}$ & $36.45 \mathrm{a}$ \\
\hline Green variety of $P$. ixocarpa & $74.22 \mathrm{a}$ & $27.54 \mathrm{a}$ & $30.10 \mathrm{a}$ & $24.45 b$ \\
\hline Purple variety of $P$. ixocarpa & $48.51 \mathrm{~b}$ & $23.99 \mathrm{ab}$ & $25.45 \mathrm{ab}$ & $22.87 b$ \\
\hline
\end{tabular}

Fruit traits: AFM, average fruit mass; LFD, longitudinal fruit diameter; TFD, transversal fruit diameter; TS, total sugars. $\sigma_{\mathrm{F}}{ }^{2}$, phenotypic variance; $\sigma_{\mathrm{A}}{ }^{2}$, genotypic variance; $\sigma_{\mathrm{G}}{ }^{2}$, environmental variance; $\mathrm{h}^{2}$, heritability; $\mathrm{CV}_{\mathrm{g}}$, coefficient of genetic variation; $\mathrm{CV}_{\mathrm{e}}$, coefficient of environmental variation. Means followed by equal letters do not differ, by the Tukey's test, at $5 \%$ probability. 
(AFM). Peña-Lomelí et al. (2004) found similar CVg values varying from 13.7 to $29.6 \%$, when evaluating seven fruit $P$. ixocarpa traits. The $\mathrm{CVg} / \mathrm{CVe}$ relation is a nondimensional parameter that indicates the superiority of the genetic compounds in relation to the environmental ones. Values higher than 1.0 indicate a higher chance of attaining gains with the selection, an important information for genetic breeding. In the present study, the obtained values were greater than 1.0 for AFM (1.10) and TS (1.02), and they were close to 1.0 for LFD (0.86) and TFD (0.89), indicating good perspectives for the selection of these traits.

The characteristics AFM, LFD, TFD, and TS showed heritabilities higher than $80 \%$ and are important traits for both processing and in natura consumption, making then good targets for genetic improvement. Indeed, increasing fruit size, fruit mass, and sugar concentration are important goals of vegetable breeding programs (Nick \& Borém, 2016). These heritability values are higher than those found by Peña-Lomelí et al. (2008) for fruit traits (37.5-57, $8 \%$ ) in the CHF1 Chapingo, a P. ixocarpa cultivar.

There were positive correlations between AFM and LFD (0.9983), and between AFM and TFD (0.9999), indicating that the bigger is the fruit, the greater is its mass (Table 3). Considering that the tomatillo fruit are widely used to prepare sauces, larger fruit with higher mass amount are desirable. Positive correlations between the transversal diameter and fruit mass (0.837), and between the longitudinal diameter and fruit mass (0.896) were also found in $P$. peruviana (Rodrigues et al., 2014). However, Silva et al. (2019) reported positive correlation between weight of five ripe fruit of $P$. angulata and fruit transversal length (0.55), but no correlation between weight of five ripe fruit and fruit longitudinal length, while Morales Saavedra et al. (2019) found no correlation between average fruit weight and equatorial fruit diameter from the same species. In the present study, a positive correlation between LFD and TFD (0.9988) was also observed, which was expected, since fruit generally have a round shape. Silva et al. (2019) observed a similar correlation (0.96) between these characteristics, when analyzing $P$. angulata fruit.

Negative correlations were observed for LFD $\mathrm{x}$ TFM (-0.9996) and TFD x TFM (-0.9972), indicating that plants which produce greater fruit had the lower production. Negative correlation was also observed for NF $x$ RS (-0.9994), indicating that plants that produce more fruit had less deposition of reducing sugars. Indeed, since the plants have limitations in the photoassimilates, directing carbons for producing more fruit can reduce the carbon amount to produce reducing sugars. These correlations can be a challenge for genetic breeding. The introduction of new genotypes could increase the genetic variability and reduce the magnitude of these correlations, allowing of the breeding for both fruit size and production, or for both number of fruit and reducing sugars.

The formation of two groups was observed using the Tocher's optimization method, by which the group 1 contains both the green and purple varieties of $P$. ixocarpa, and group 2 contains only $P$. philadelphica. The intragroup distance was 28.13 ,

Table 3. Pearson's correlation coefficient from fruit traits of Physalis ixocarpa and P. philadelphica.

\begin{tabular}{|c|c|c|c|c|c|c|c|c|}
\hline Trait & AFM & SS & LFD & TFD & TFM & $\mathrm{NF}$ & $\mathrm{RS}$ & TS \\
\hline AFM & 1 & 0.8835 & $0.9983^{*}$ & $0.9999 * *$ & -0.9965 & -0.6940 & 0.6694 & -0.7622 \\
\hline SS & & 1 & 0.8538 & 0.8783 & -0.8401 & -0.2739 & 0.2415 & -0.3683 \\
\hline LFD & & & 1 & $0.9988^{*}$ & $-0.9996 *$ & -0.734 & 0.7113 & -0.7984 \\
\hline TFD & & & & 1 & $-0.9972 *$ & -0.7345 & 0.6760 & -0.7679 \\
\hline TFM & & & & & 1 & 0.7518 & -0.7292 & 0.8137 \\
\hline $\mathrm{NF}$ & & & & & & 1 & $-0.9994 *$ & 0.9950 \\
\hline RS & & & & & & & 1 & -0.9911 \\
\hline TS & & & & & & & & 1 \\
\hline
\end{tabular}

*, $* *$ Significant at 5 and $1 \%$, respectively, by the t-test. Fruit traits: AFM, average fruit mass; SS, soluble solids; LFD, longitudinal fruit diameter; TFD, transversal fruit diameter; TFM, total fruit mass; NF, number of fruit; RS, reducing sugars; TS, total sugars. 
and intragroup 1 was 5.78. A hierarchical dendrogram was obtained using the UPGMA method (Figure 1) with a cophenetic correlation coefficient (0.99), a value that indicates a good fitting of the dendrogram and the matrix of genetic dissimilarity. However, using a cutoff calculated by the method proposed by Mojena (1977), the three species were grouped in the same group, even though the purple and the green P. ixocarpa varieties have shown the smallest distance between them. Thus, the Tocher's method was more sensitive to identify the distance between the two species, in comparison with the UPGMA.

The TFD, TS, and LFD traits showed the major contributions for genetic divergence $(28.81,25.34$, and $17.35 \%$, respectively), corresponding to $71.5 \%$ of the genetic diversity. TFD and LFD are related to the size and shape of fruit, and TS is related to the acidity and sweetness, traits that are important for the acceptance by consumers. These traits should be carefully considered by the breeding programs, since they correspond to most of the genetic diversity found in the present study, which allows to direct future crossings for the tomatillo genetic breeding, including the possibility of heterosis exploitation. The remaining five traits corresponded to

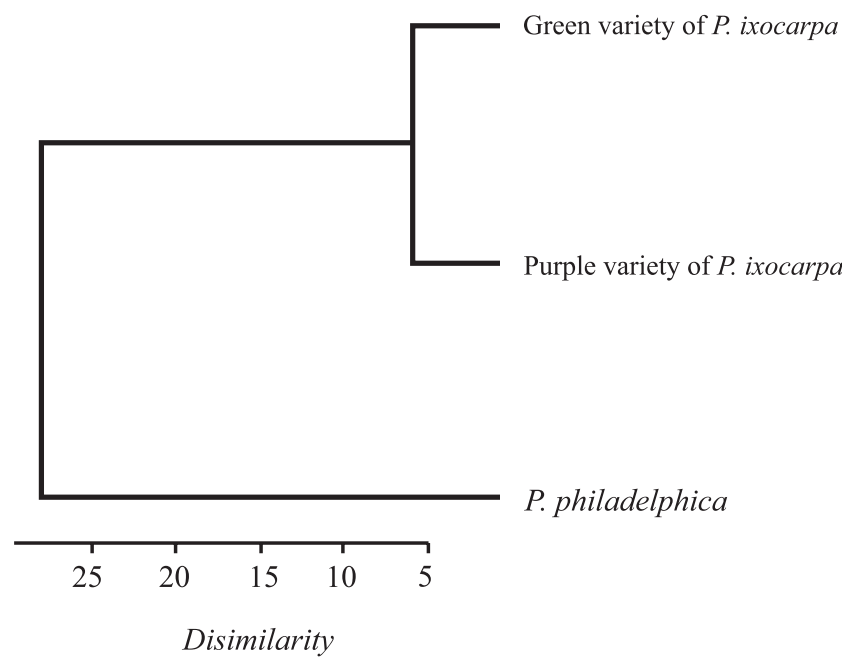

Figure 1. Hierarchical grouping of Physalis philadelphica and the green and purple varieties of $P$. ixocarpa, using the unweighted pair group method with arithmetic mean (UPGMA) based on the matrix of Mahalanobis distance from eight fruit traits.
$28.5 \%$, varying from 1.06 to $10.33 \%$ of the variability (Table 4). These contribution values were higher than those found by Silva et al. (2019), who evaluated 12 traits in six accessions of $P$. angulata, including the number of fruit per plant $(6.98 \%)$, fruit longitudinal length $(5.60 \%)$, fruit transversal length $(6.49 \%)$ and soluble solids (4.14\%). Fruit diameter (40.91\%) was also the main trait contributing for the genetic diversity of 12 accessions of $P$. peruviana (Kumar et al., 2016). Therefore, both shape and composition fruit traits are important for the genetic variability between $P$. ixocarpa and P. philadelphica.

Although Waterfall (1967) considered P. ixocarpa and $P$. philadelphica the same species and adopted $P$. philadelphica to name the Mexican tomatillos, as well as Santiaguillo Hernández \& Blas Yáñez (2009), other studies related them as different species due to flower and fruit traits (Lagos B. et al., 2005; Zamora-Tavares et al., 2015; Martínez et al., 2017). In the present study, total sugars can be considered a target to distinguish these two species, besides being a good target for the genetic breeding of tomatillo crop.

The two studied Physalis species show variability between important traits that are targets for genetic breeding, therefore, they have a high potential for their cultivation in Brazil.

Table 4. Relative contribution of eight fruit traits for the genetic diversity among Physalis philadelphica and the green and purple varieties of Physalis ixocarpa, using the Singh's (1981) method.

\begin{tabular}{lcc}
\hline Trait & S.j & $(\%)$ \\
\hline AFM & 7.64 & 5.74 \\
SS & 1.41 & 1.06 \\
LFD & 23.11 & 17.35 \\
TFD & 38.36 & 28.81 \\
TFM & 4.80 & 3.60 \\
NF & 10.30 & 7.74 \\
RS & 13.76 & 10.33 \\
TS & 33.74 & 25.34 \\
\hline
\end{tabular}

S.j, values of relative contribution for each fruit trait. Fruit traits: AFM, average fruit mass. SS, soluble solids; LFD, longitudinal fruit diameter; TFD, transversal fruit diameter; TFM, total fruit mass; NF, number of fruit; RS, reducing sugars; TS, total sugars. 


\section{Conclusions}

1. The traits average fruit mass, longitudinal fruit diameter, transversal fruit diameter, and total sugars show a significant genetic variation and high values of heritability, therefore, they are suitable targets for the genetic breeding of the evaluated Physalis species.

2. Physalis philadelphica and the green and purple varieties of $P$. ixocarpa are genetically divergent for average fruit mass, transversal and longitudinal diameters of fruit, and total sugars, which are good targets for genetic breeding.

3. Total sugars can discriminate $P$. ixocarpa from $P$. philadelphica.

4. The species can be discriminated by the Tocher's method, using physicochemical fruit traits with higher contribution for the average fruit mass and the transversal and longitudinal diameters.

\section{Acknowledgements}

To Fundação de Amparo à Pesquisa do Estado da Bahia (Fapesb), for scholarship granted.

\section{References}

BARROSO, N. dos S.; FONSECA, J.S.T.; NASCIMENTO, M.N. do; PELACANI, C.R. Physalis development according to the growing season in the semi-arid region of the Bahia state, Brazil. Pesquisa Agropecuária Tropical, v.48, p.429-435, 2018. DOI: https://doi.org/10.1590/1983-40632018v4854173.

BARROSO, N. dos S.; SOUZA, M.O. de; RODRIGUES, L.C. da S.; PELACANI, C.R. Maturation stages of fruits and physiological seed quality of Physalis ixocarpa Brot. Ex Hormen. Revista Brasileira de Fruticultura, v.39, e-151, 2017. DOI: https://doi.org/10.1590/0100-29452017151.

CHARRAD, M.; GHAZZALI, M.; BOITEAU, V.; NIKNAFS, A. NbClust: an $\mathrm{R}$ package for determining the relevant number of clusters in a data set. Journal of Statistical Software, v.61, p.136, 2014. DOI: https://doi.org/10.18637/jss.v061.i06.

CRUZ, C.D. Genes: a software package for analysis in experimental statistics and quantitative genetics. Acta Scientiarum. Agronomy, v.35, p.271-276, 2013. DOI: https://doi.org/10.4025/actasciagron.v35i3.21251.

DELGADO-ALVARADO, E.A.; ALMARAZ-ABARCA, N.; ESCAMIROSA-TINOCO, C.; URIBE-SOTO, J.N.; ÁVILAREYES, J.A.; TORRES-RICARIO, R.; CHAÍDEZ-AYALA, A.I. Potential of random amplified microsatellites (RAMS) to typify and discriminate varieties of Physalis ixocarpa Brot. ex Hornem. Emirates Journal of Food and Agriculture, v.30, p.396-403, 2018. DOI: https://doi.org/10.9755/ejfa.2018.v30.i5.1684.
GOLUBKINA, N.A.; KEKINA, H.G.; ENGALICHEV, M.R.; ANTOSHKINA, M.S.; NADEZHKIN, S.M.; CARUSO, G. Yield, quality, antioxidants and mineral nutrients of Physalis angulata L. and Physalis pubescens L. fruits as affected by genotype under organic management. Advances in Horticultural Science, v.32, p.541-548, 2018. DOI: https://doi.org/10.13128/ahs-22211.

KUMAR, V.; SAHAY, S.; AHMAD, S.; NIRGUDE, V.; SINGH, R.S.; KHANDELWAL, A. Genetic divergence of cape gooseberry (Physalis peruviana L.) Genotypes in India. International Journal of Agriculture, Environment and Biotechnology, v.9, p.1-4,2016. DOI: https://doi.org/10.5958/2230-732X.2016.00001.2.

LAGOS B., T.C.; VALLEJO C., F.A.; CAETANO, C.M.; MUÑOZ F., J.E.; CRIOLLO E., H. Comportamiento meiótico de algunos genotipos de Physalis peruviana L. Fitotecnia Colombiana, v.5, p.1-12, 2005.

MALDONADO, E.; PÉREZ-CASTORENA, A.L.; GARCÉS, C.; MARTÍNEZ, M. Philadelphicalactones $\mathrm{C}$ and $\mathrm{D}$ and other cytotoxic compounds from Physalis philadelphica. Steroids, v.76, p.724-728, 2011. DOI: https://doi.org/10.1016/j. steroids.2011.03.018

MANTEL, N. The detection of disease clustering and generalized regression approach. Cancer Research, v.27, p.209-220, 1967.

MARTÍNEZ, M.; VARGAS-PONCE, O.; RODRÍGUEZ, A.; CHIANG, F.; OCEGUEDA, S. Solanaceae family in Mexico. Botanical Sciences, v.95, p.131-145, 2017. DOI: https://doi.org/10.17129/botsci.658.

MOJENA, R. Hierarchical grouping methods and stopping rules: an evaluation. The Computer Journal, v.20, p.359-363, 1977. DOI: https://doi.org/10.1093/comjnl/20.4.359.

MORALES SAAVEDRA, J. del C.; RODRÍGUEZ ZARAGOZA, F.A.; CABRERA TOLEDO, D.; SÁNCHEZ HERNÁNDEZ, C.V.; VARGAS-PONCE, O. Agromorphological characterization of wild and weedy populations of Physalis angulata in Mexico. Scientia Horticulturae, v.246, p.86-94, 2019. DOI: https://doi.org/10.1016/j.scienta.2018.10.055.

NAUMOVA, N.; NECHAEVA, T.; SAVENKOV, O.; FOTEV, Y. Yield and fruit properties of husk tomato (Physalis phyladelphica) cultivars grown in the open field in the south of West Siberia. Horticulturae, v.5, 19, 2019. DOI: https://doi.org/10.3390/ horticulturae 5010019

NICK, C.; BORÉM, A. (Ed.). Melhoramento de hortaliças. Viçosa: Ed.. da UFV, 2016. p.427.

OLIVEIRA, J.A.R. de; MARTINS, L.H. da S.; VASCONCELOS, M.A.M. de; PENA, R. da S.; CARVALHO, A.V. Caracterização física, físico-química e potencial tecnológico de frutos de camapu (Physalis angulata L.). Revista Brasileira de Tecnologia Agroindustrial, v.5, p.573-583, 2011. DOI: https://doi.org/10.3895/ S1981-36862011000200009.

PEÑA-LOMELÍ, A.; CONTRERAS, A.M.; PÉREZ, M.E.R.; CARBALLO CARBALLO, A.; RODRÍGUEZ PÉREZ, J.E.; MALDONADO, M.M. Parámetros genéticos de tomate de cáscara (Physalis ixocarpa Brot.) variedad verde Puebla. Revista Fitotecnia Mexicana, v.27, p.1-7, 2004. 
PEÑA-LOMELÍ, A.; MOLINA-GALÁN, J.D.; SAHAGÚNCASTELLANOS, J.; ORTIZ-CERECERES, J.; MÁRQUEZSÁNCHEZ, F.; CERVANTES-SANTANA, T.; SANTIAGUILLO HERNÁNDEZ, J.F. Parámetros genéticos en la variedad CHF1 Chapingo de tomate de cáscara (Physalis ixocarpa Brot.). Revista Chapingo Serie Horticultura, v.14, p.5-11, 2008. DOI: https://doi.org/10.5154/r.rchsh.2006.11.046.

RAIJ, B. van; ANDRADE, J.C. de; CANTARELLA, H.; QUAGGIO, J.A. (Ed.). Análise química para avaliação da fertilidade de solos tropicais. Campinas: IAC, 2001. 285p.

RODRIGUES, F.A.; PENONI, E. dos S.; SOARES, J.D.R.; SILVA, R.A.L.; PASQUAL, M. Caracterização física, química e físicoquímica de physalis cultivada em casa de vegetação. Ciência Rural, v.44, p.1411-1414, 2014. DOI: https://doi.org/10.1590/0103$8478 \mathrm{cr} 20130743$.

SANTIAGUILLO HERNÁNDEZ, J.F.; BLAS YÁÑEZ, S. Aprovechamiento tradicional de las especies de Physalis en México. Revista de Geografía Agrícola, n.43, p.81-86, 2009.

SANTIAGUILLO HERNÁNDEZ, J.F.; VARGAS PONCE, O.; GRIMALDO JUÁREZ, O.; MAGAÑA LIRA, N.; CARO VELARDE, F.; PEÑA LOMELÍ, A.; SÁNCHEZ MARTÍNEZ, J. Perfil del diagnóstico de la red tomate de cáscara. Chapingo: Universidad Autónoma Chapingo, 2012. 46p.

SANTOS, H.G. dos; JACOMINE, P.K.T.; ANJOS, L.H.C. dos; OLIVEIRA, V.A. de; LUMBRERAS, J.; COELHO, M.R.; ALMEIDA, J.A. de; CUNHA, T.J.F.; OLIVEIRA, J.B. de. Sistema brasileiro de classificação de solos. 3.ed. rev. e ampl. Brasília: Embrapa, 2013. 353p.

SILVA, H.K. da; PASSOS, R.S.; SCHNADELBACH, A.S.; MOREIRA, R.F.C.; CONCEIÇÃO, A.L. da S.; LIMA, A.P.
Selection of morphoagronomic descriptors in Physalis angulata L. using multivariate techniques. Journal of Agricultural Science, v.11, p.289-302, 2019. DOI: https://doi.org/10.5539/jas.v11n1p289.

SINGH, D. The relative importance of characters affecting genetic divergence. Indian Journal of Genetics and Plant Breeding, v.41, p.237-245, 1981.

SINGH, D.B.; AHMED, N.; MIRZA, A.; LAL, S.; PAL, A.A. Introduction, characterisation and evaluation of husk tomato (Physalis ixocarpa Brot.) genotypes under temperate climate. Indian Journal of Plant Genetic Resources, v.26, p.226-230, 2013.

SOKAL, R.R.; ROHLF, F.J. The comparison of dendrograms by objective methods. Taxon, v.11, p.33-40, 1962. DOI: https://doi.org/10.2307/1217208.

WATERFALL, U.T. Physalis in Mexico, Central America and the West Indies. Rhodora, v.69, p.82-120, 1967.

YEMM, E.W.; WILLIS, A.J. The estimation of carbohydrates in plant extracts by anthrone. Biochemical Journal, v.57, p.508-514, 1954. DOI: https://doi.org/10.1042/bj0570508.

YILDIZ, G.; İZLI, N.; ÜNAL, H.; UYLAŞER, V. Physical and chemical characteristics of goldenberry fruit (Physalis peruviana L.). Journal of Food Science and Technology, v.52, p.2320-2327, 2015. DOI: https://doi.org/10.1007/s13197-014-1280-3.

ZAMORA-TAVARES, P.; VARGAS-PONCE, O.; SÁNCHEZMARTÍNEZ, J.; CABRERA-TOLEDO, D. Diversity and genetic structure of the husk tomato (Physalis philadelphica Lam.) in Western Mexico. Genetic Resources and Crop Evolution, v.62, p.141-153, 2015. DOI: https://doi.org/10.1007/ s10722-014-0163-9. 